\title{
Research on life design in (South) Africa: a qualitative analysis
}

\author{
Jacobus G Maree
}

\begin{abstract}
No country, including South Africa, has been left untouched by the global economic meltdown in 2008 and fears that another financial meltdown could be imminent. This article reports on the emergence of career construction and life design in response to changes in the world of work. It explains the essence of career construction and life design and discusses their value in 2 Ist century (South) Africa. It also discusses the re-emergence of adaptability as a pivotal 'survival skill' in the 2 Ist century and its importance in career counselling contexts. The second part of the article covers the analysis of six case studies on career construction and design counselling. Qualitative data analysis was used to identify common themes and subthemes in the case studies. It emerged that life design counselling enabled the participants to understand themselves better and construct new selves, broadened their perspectives on career-life issues, facilitated change in their lives, encouraged action, and imbued new hope in them. However, more research is needed on such counselling, especially in group contexts.
\end{abstract}

\section{Keywords}

Adaptability, career construction, life design in South Africa, meta' approach to data analysis, thematic data analysis

Numerous changes have occurred in the workplace and are fast changing the theory and practice of career counselling worldwide. The changes precipitated by the fourth economic wave and the fifth information wave (Gurri, 2013) in particular have left 21 st century youth with no choice but to become more adaptable and employable (instead of merely finding employment) and thereby prepare themselves for the inevitable restructuring and transformation of the workplace (Maree, 2013).

Twenty-first century workers' perceptions of work-related issues such as the goals, values, and the meaning they attach to work have changed dramatically as they have attempted to respond to

Faculty of Education, University of Pretoria, South Africa

Corresponding author:

Jacobus G Maree, Faculty of Education, University of Pretoria, Pretoria 0002, South Africa.

Email: kobus.maree@up.ac.za 
the fourth economic wave (Maree \& Pollard, 2009). The numerous transitions they now have to negotiate have increased their levels of work-related anxiety (Maree, 2013), and it is the task of career counsellors to help them deal with these anxieties, establish clear goals for their lives, and instil in them a sense of the meaningfulness of life (Strauser, Lustig, \& Ciftci, 2008).

In the 21st century, more than ever before, workers are confronted with transformation, its impact on the world of work, and the need to make transitions at various levels and in various ways in order to succeed in an uncertain environment. These transitions can involve being laid off from work, moving from one job to another, moving from one work-related assignment to another, and dealing with one work trauma after another. Authors have attempted to create new terms to describe what is currently happening in the world of work. Terms such as the following have become well known in the work-related literature (Maree, 2013, 2014):

1. Customised careers. Benko and Weisberg (2007) maintain that many workers are losing interest in climbing the corporate ladder and are focusing more on meeting their family's and their own needs. These workers are less eager to give up their personal time for their careers and, instead, tailor ('customise') their career portfolios (i.e., the series of positions they occupy) to suit their own needs instead of merely serving the needs of their employers (M. L. Savickas, personal communication, 22 April 2014).

2. Kaleidoscopic careers. Mainiero and Sullivan (2005) argue that careers have become dynamic. Kaleidoscopic careers are in a state of flux; created on workers' own terms and not dictated, career-related issues are continually being 're-purposed', leading to the creation of careers dictated and defined by people's own values, choices, and inclinations.

3. Post-industrial careers. Two decades ago, Gershuny (1993) contended that the idea of 'stable' work environments and characteristics was becoming outdated and that workers had to redefine and re-invent themselves continually in the workplace.

4. Boundaryless careers. The tradition of negotiating and signing long-term contracts with organisations is being questioned as many employees today prefer to work independently and are less prepared to work within the confines of one work environment or organisation only (Arthur, 1994; Arthur \& Rousseau, 1996).

5. Portfolio careers. The idea of working for one employer in one organisation is rapidly disappearing as self-employment is preferred by many workers today (Fenwick, 2004). An increasing number of workers prefer to negotiate multiple contracts with different organisations and thereby 'market' and 'sell' their skills more widely in a self-employed capacity (Handy, 1995).

6. Protean (a reference to the Greek god Proteus who could change his shape as and when he wanted to) careers. Workers are increasingly expected to demonstrate career resilience in the face of negative experiences in the workplace (Ungar, 2012) and to learn to cope with and master 21st century technology changes and developments (Baruch, 2004; Hall, 1996).

7. Hourglass economy careers. Different views are held on how the world of work will evolve. Campbell et al. (2001) and Moynagh and Worsley (2005), for instance, believe that the future labour force will be divided into different sections, with an increase in demand for highly skilled professionals and managers as well as for lowly skilled employees (i.e., the global economy will increasingly assume the shape of an hourglass). Keep and Brown (2005), Applebaum et al. (2003), Ehrenreich (2002), and Finegold (1999), on the other hand, believe that the future economy will be characterised by 'islands' of highly skilled and highly paid employees in a vast sea of lowly skilled and lowly paid employees.

8. Dejobbing. Changes in the global economy, brought about by the global economic meltdown, have led to millions of 'insecure workers'. This term relates to temporary, contingent, 
casual, contract, freelance, part-time, external, atypical, adjunct, consultant, and selfemployed workers (Savickas, 2013).

In summary, the above terms, each containing elements of insecurity and uncertainty, point to the following trends:

1. The importance of becoming employable instead of merely trying to find a job for the rest of one's lifetime;

2. The inclination of many workers to manage their own careers instead of finding employment and being controlled by forces beyond themselves;

3. An increase in the incidence of work-related trauma and attempts to deal with its impact on workers.

Because of all the work-related changes in the 21 st century and their impact on workers (including the increase in the number of job opportunities on offer), many career counsellors today believe that a person's career-life story can 'best' be told by combining postmodern techniques with traditional techniques. This is confirmed by the shift that has taken place over the past two decades, in particular towards including both 'objective' and 'subjective' information in career counselling. Postmodern techniques and strategies include autobiographies, with the emphasis on helping people find meaning during the interpretation of data obtained from personality (including interest and aptitude) questionnaires/inventories and tests. To remain relevant and useful to their clients, career counsellors should themselves become more adaptable and open-minded regarding they 'best' ways to collect data. They should also help clients do the following:

- Interpret their own interests, ability, and values;

- Identify their major life themes;

- Choose careers;

- Construct themselves;

- Design successful lives, in which they will make meaningful social contributions.

Changes in the world of work need to be interpreted and responded to against the background of two forces competing for control of the occupational world (Gurri, 2013). Hierarchy, on the one hand, signifies the time-honoured and almost general acceptance of the tradition of power characterised by centralisation, a top-down approach, 'standardised' processes, slowness, long-term plans, respect for those in power, and disrespect for less powerful entities and those who are not part of the 'in-group' in a corporation. Networking, on the other hand, which emerged during the fifth wave, provides 'lesser', under- and unacknowledged people with the means to contact (connect with) other people and organisations almost instantaneously (Gurri, 2013). A wide variety of electronic devices (such as PCs, laptops, tablets, game consoles, and satellite TV), digital applications (such as cell and smart phones, personal media players, video phones, digital cameras, and medical imaging), and associated instant messaging subscription programmes such as WhatsApp facilitate instant, universal connectivity. Networking and connectivity allow almost unlimited freedom of expression, show little respect for power, are immediate, lack permanence, and enable people to display unbounded creativity and invention. All people can now associate freely and make themselves heard.

The effects of the 'struggle' between these two fundamentally irreconcilable forces on the world of work are far-reaching as all people now have the opportunity to construct themselves and design successful lives, provided they know the 'rules of the new game'. We, as career counsellors, should 
familiarise ourselves with the effects of the above 'struggle' on the world of work so that we can provide up-to-date career counselling to our clients.

The theory and praxis of career counselling have, in many countries, responded well to changes in the global economy over the past two decades. These positive responses are particularly noticeable in the United States, parts of Europe, Australia, and New Zealand, but less so in many other countries, including most countries in Africa (even South Africa). This is because the economies of these countries are still largely structured the way they were many decades ago. It should be borne in mind, however, that the impact of (a) changes in the global economy and (b) the battle between traditional hierarchical structures and the connectivity and instant networking that characterise postmodern work environments is felt across the world, irrespective of the state of local economies and the nature of economic structures.

The theory and praxis of career counselling have, in many countries, responded well to changes in the global economy over the past two decades. These positive responses are particularly noticeable in the United States, parts of Europe, Australia, and New Zealand, but less so in many other countries, including most countries in Africa (even South Africa). This is because the economies of these countries are still largely structured the way they were many decades ago. It should be borne in mind, however, that the impact of (a) changes in the global economy and (b) the battle between traditional hierarchical structures and the connectivity and instant networking that characterise postmodern work environments is felt across the world, irrespective of the state of local economies and the nature of economic structures.

In South Africa, as in many other parts of the world, traditional career assessment and career counselling are still the order of the day. Few researchers and practitioners have embraced the idea of an integrated, quantitative + qualitative approach to career counselling, possibly because of the high unemployment rate in the country and the fact that most South Africans have little choice but to accept any form of employment just to earn a living, perhaps believing that postmodern career counselling will not help them find employment. Career counsellors may also believe that an integrated, quantitative + qualitative approach to career counselling is too time-consuming, expensive, and more suited to one-on-one career counselling settings.

Career construction theory (CCT; Savickas, 2005, 2011) and life design counselling (Savickas et al., 2009) are discussed below.

\section{Career construction theory}

Savickas (2014, personal communication) states that CCT is embedded in social constructionism rather than logical positivism, does not theorise about independently existing reality, and assumes that people live in (and through) language and construct social reality through their interpersonal affiliations. CCT should be seen as a narrative construction designed to tell a useful story about vocational behaviour and its facilitation. CCT does not claim to be a scientific theory (Davies \& Harré, 1990) or to propose or promote an essentialist reality model.

CCT informs Savickas' $(2005,2014)$ career construction discourse strategy (a meaning-making approach) and should be viewed as a metatheory that merges the following three definitive theoretical approaches on career-related assessment, choices, and performance:

1. The differential (finding the best possible person-environment fit - Parsons, 1909, 2005) approach;

2. The developmental (lifespan-life space; how people adapt and develop during their lives - Super, 1990) approach; 
3. The (psycho-)dynamic (narrative or career-life story) approach (Hartung, 2011; Savickas, 2005, 2011, 2014).

The first two approaches are predicated on the assumption that CCT provides career counsellors with a proven 'recipe' to match people to, for instance, subjects, school types, fields of study, types of tertiary training institutions, and types of jobs, occupations, careers, and work environments. These approaches and their associated strategies are based on people's measured traits on the one hand and the requirements of specific work environments on the other hand, as well as people's readiness to occupy certain positions in organisations (Savickas, 2005). CCT aims to devise a plan of action which (a) refutes the generally accepted premise that these two approaches will yield an 'optimal' fit between people and their environments and (b) demonstrates that this premise has in fact become inadequate in the rapidly changing 21 st century. The global economy of today poses new challenges to career counsellors and clients alike. At the heart of these challenges is the need to focus on the subjective side of clients' career-life stories in addition to considering the 'objective' side of these stories. The subjective side can be elicited through qualitative, narrative techniques and strategies. The psycho-dynamic, narrative, or storied perspective obtained through these techniques and strategies complements the first two approaches by allowing patterns, themes, and meaning to emerge from clients' career-life stories and lived experiences. Career construction counselling can also enhance clients' sense of self (Maree, 2012a).

CCT holds that people choose careers and 'construct' themselves by obtaining personal meaning from numerous subjective, career-related, and lived experiences. By emphasising constructs such as life portraits, narratability, and biographicity (Savickas, 2011), CCT helps explain people's lived experiences and the manner in which they choose careers, construct themselves, and design successful lives. Put briefly, CCT involves asking people to first recount their biographies and then create life portraits. After this, self-reflection, reflexivity, and self-making are set in motion and promoted.

Duarte maintains that, from a career construction perspective, career counselling is an uninterrupted, interactive process that never stands apart from emotions and feelings. It is a process that facilitates problem solving and decision making within the context in which people live, act, develop, work, and adapt (Duarte, 2009, 2010).

\section{Life design counselling}

CCT is a co-constructive process during which life design begins or is maintained and promoted. The aim is to encourage individuals to function more effectively in changing, complex, and codependent contexts. A participatory and dynamic process is encouraged rather than rigid adherence to a set of inflexible rules. People are considered authors who continually advance their career-life stories. They are encouraged to write and rewrite these stories and to link their work roles with their career self-concepts (Savickas, 2002).

Life design discourse takes into account the demands and needs people are confronted with in their unique contexts. Consequently, the focus is on career decision making, career development, and, especially, career construction. The ultimate aim is to advance the design of people's lives and enable them to become more flexible in adapting to the numerous challenges posed by change in different contexts (Campbell \& Ungar, 2004a, 2004b).

Three models of life design are now discussed below. It should be noted that all these models emphasise the subjective aspect of career counselling (including the notion of meaning-making or the construction of meaning). 


\section{Life design models}

The first life design model incorporates narrative assessment and discourse-facilitating techniques (including the lifeline, the collage, and role identification) to facilitate life design. These techniques are augmented by interactive group discussions that focus on the personalised application of techniques and strategies (Zunker, 1998). The second model (Campbell \& Ungar, 2004a, 2004b) is described as holistic, developmental, context-sensitive, and proactive with the aim of promoting clients' career-life stories. It blends career construction with time-, context-, and individualitybound factors as well as time-, context-, and individuality-defined factors. Moreover, it aims to enable clients to progress smoothly through seven career-life 'chapters' and to advance from selfreflection (understanding their perceptions of their 'limitations' and identifying what they have, want, hear, see, and perceive) to reflexivity (building on their reflections and moving forward by embracing their preferred career-life story and eventually healing themselves by realising this story) (Campbell \& Ungar, 2004a, 2004b; Maree \& Pollard, 2009).

Savickas et al. (2009) state that life design is based on the following five assumptions about people and their work lives: (a) contextual possibilities, (b) dynamic processes, (c) non-linear progression, (d) multiple perspectives, and (e) personal patterns. Moreover, the life design model is structured to be life-long, holistic, contextual, and preventive. It expresses career-related behaviour and development and is based on career construction discourse (Savickas, 2005) and self-construction discourse (Guichard, 2005). Career counselling is regarded as a continuous, collaborative course of action closely intertwined with emotions. It enables people to solve problems and make informed decisions in their particular contexts and promote their career-life stories (Duarte, 2009, 2010).

It is becoming increasingly difficult to 'predict' the future and to know what factors will codetermine success in a career and in life. Career-lives should accordingly be redesigned when needs, interests, and life experiences change (Savickas, 1993).

\section{Career adaptability}

Soresi, Nota, Ferrari, and Solberg (2008) argue that the value of career counselling depends on the extent to which it succeeds in producing meaningful changes in people's career-life stories. Pulakos et al. (2002) believe that adaptability can be divided into categories such as resolving challenges, coping with unpredictable situations, getting to grips with new assignments, proving the ability to adapt to change, transitioning personal and cultural crossroads, and handling work stress and crisis situations.

Savickas (1997) regards career adaptability as 'the readiness to cope with the predictable tasks of preparing for and participating in the work role and with the unpredictable adjustments prompted by changes in work and working conditions' (p. 257). He believes that career adaptability augments people's employability. Savickas (2005) therefore regards career adaptability as a pivotal aspect of CCT in that CCT deals with developmental tasks and role transitions relating to career concern, career control, career curiosity, and career confidence. Career concern relates to people's own career future and demonstrates their belief that they have a future worth getting ready for and that their efforts to prepare themselves will enhance their future lives. Career control denotes optimism about the future, initiates concern about ownership of the future, and shows that people accept ownership of their choice of career. Career curiosity refers to the types of careers a person may be interested in and the opportunities that these careers may present (Savickas, 2005). It also refers to constructive career examination and entails a pragmatic approach to the future (Hartung, 2007). Career confidence refers to people's belief in their capacity to solve problems and makes it obvious that people can perform efficiently. 


\section{Six-step life design intervention strategy}

The life design intervention model and associated strategy comprise six general steps informed by the unique experiences of individual people (Savickas et al., 2009). In Step 1, the problem is defined jointly by the counsellor and client and informed by what the client is hoping to gain from the intervention. In Step 2, the client is encouraged to explore his or her existing system of subjective identity forms (a subjective identity form is the way people see themselves and others in particular contexts and how they relate to others and the objects in this context - Guichard, 2008b; Savickas et al., 2009). In Step 3, the focus is shifted towards broadening the perspectives of the client, and the story is revised. In Step 4, the client places the current problem within his or her revised story. In Step 5, the client is supported in identifying relevant activities to carry out and to actualise his or her newly established identity. Step 6 comprises short-, medium-, and long-term follow-ups.

The next section covers life design research in South Africa over the past six years. More particularly, six case studies conducted at Master's level are discussed. This is followed by a summary of the common themes and subthemes that emerged from the case studies.

\section{Life design research in South Africa during the past five years}

In the research study, I wanted to ascertain the effect of life design counselling on the six participants who differed in terms of age, gender, mother tongue, and level of training. More specifically, I wanted (a) to analyse thematically the six sets of themes and subthemes that emerged during the individual studies to establish which were the common themes and subthemes and (b) to determine the impact of the specific life design counselling intervention on the participants.

\section{Method}

\section{Research paradigm}

All six case studies were based on a qualitative, interpretive research paradigm.

\section{Participants}

Six participants were purposively selected to participate in six case studies (conducted by Master's level researchers; Table 1). In the first case study (Maree \& Pollard, 2009), the participant 'Peter' (pseudonyms were used in all the case studies) was an English-speaking White adolescent, aged 18, from an average socio-economic environment (selection criteria called for an adolescent who had expressed a need for career counselling). In the second case study (Maree \& Hansen, 2011), 'Maria' was a 17-year-old, Black, pregnant Tswana-speaking adolescent from a socio-economically depressed area. Maria lived with her magogo or grandmother (selection criteria called for an unwed adolescent who had expressed a need for career counselling). In the third case study (Maree \& Hancke, 2011), 'Jim' was a White, 15-year-old English-speaking learner in Grade 9 who stuttered (selection criteria called for an adolescent who stuttered and who had sought career counselling). In the fourth case study (Maree, Nkambule, Erasmus, Hansen, \& Symington, 2010), 'Lindelwa' was a 24-year-old Siswati-speaking woman (the last-born in her family) (selection criteria called for a disadvantaged early career woman who had expressed a need for career counselling). In the fifth case study (Maree \& Crous, 2012), 'Mary-Ann' was an 18-year-old, Pedispeaking Black adolescent. She had been abandoned by her mother at the age of 1 year and 3 months, and her grandmother had taken her in. She lived with her grandmother until the age of 
Table I. Participants' profiles.

\begin{tabular}{llllll}
\hline Name & Age & Gender & SES & Mother tongue & Race \\
\hline Peter & 18 & Male & Average & English & White \\
Maria & 17 & Female & Low & Tswana & Black \\
Jim & 15 & Female & Average & English & White \\
Lindelwa & 24 & Female & Low & Siswati & Black \\
Mary-Ann & 18 & Male & Low & Pedi & Black \\
Shane & 25 & Male & High & Afrikaans & White
\end{tabular}

15 at which time she was moved to a place of safety and later to a children's home (selection criteria called for an abandoned teenager who had expressed a need for career counselling). In the sixth case study (Maree \& Gerryts, 2014), 'Shane' was a 25-year-old Afrikaans-speaking White man who had studied chemical engineering (selection criteria called for an early career male who had expressed a need for career counselling).

\section{Instruments}

Data-gathering instruments and strategies included a combination of postmodern techniques such as eliciting role models, creating Collages, conducting the Career Construction Interview (CCI; previously the Career-Story Interview) (Savickas, 2011), creating a Life line, and administering the Career Interest Profile (CIP), which yields qualitative career-related information (Maree, 2010, 2011) and the Career Adapt-Abilities Scale (CAAS) (Maree, 2012b), analysing the results qualitatively.

The CCI comprises six questions. Whereas clients' goals for counselling can be uncovered by their responses to the opening question, the next four (life story-related) questions elicit clients' life stories and identify the initial pain (or sometimes pleasure) in their lives. The last question is used to elicit their three earliest recollections. The $C A A S$ can be used to help people deal with challenges to their working lives and managing occupational transitions, developmental tasks, and work traumas (Savickas \& Porfeli, 2012). Career adapt-abilities include the factors concern, control, curiosity, and confidence, which are psychosocial competencies, rather than behaviours that produce adaptation and its outcomes. A cross-sectional survey $(N=464)$ was carried out to determine the validity and reliability of the CAAS in South Africa (Maree, 2012b). The validity and reliability of the CAAS-South African Form (CAAS-SA) were investigated empirically. Confirmatory factor analysis, item analysis, and reliability analysis were carried out. Internal consistency estimates for the subscale and total scores ranged from good to excellent. The factor structure was similar to the structure computed for combined data from 13 countries.

\section{Procedure}

During the first stage (constructing a working alliance), the focus was on facilitating understanding of the problems facing the participants. It was explained to them that they were the architects of their lives, but that they and the researchers would collaborate in co-constructing their futures and co-designing their lives. In other words, the idea of co-constructing a working alliance was established.

During the second stage (mapping and exploring the system of subjective identity forms) (Guichard, 2005), self-reflection was facilitated and the connection between the participants' past 
experiences discussed. The level of concurrence between their current identities and their desired identities was investigated.

During the third stage (opening perspectives; discovering, re-authoring, reorganising, revising, and revitalising stories), the participants' life stories were repeated (based on the data obtained during Sessions 1 and 2), and the rewriting of these life stories commenced. The researchers were at pains to ensure that the participants did not see themselves as failures, unable to construct themselves, or destined to be 'second best', but, rather, as willing to work on realising their identified assets and strengths and to consider their 'weaknesses' as potential strengths.

During the fourth stage (positioning the problem in the new story and interpreting it from a novel perspective), re-interpretation of the participants' situations presented an exciting new perspective and twist in the plot: reconfirmation of their ability to realise their desired identities. The participants were helped to discover existing assets and support structures in their lives.

During the fifth stage (specifying some activities to enable participants to try to actualise that identity), the participants and the researchers decided on ways to actualise the envisaged, co-constructed life design strategies. The initial aims were then revisited, and overall reflexivity was facilitated.

The participants were requested to peruse the co-constructed plans of action (drawn up by themselves and the researchers) and to confirm that these plans were appropriate and feasible.

During the sixth stage, short-, medium-, and long-term follow-ups took place to monitor the participants' progress.

\section{Ethical considerations}

Ethical approval for the research was obtained from the University of Pretoria. Written informed consent was obtained from all the participants to record and transcribe all the sessions, which were held at the same venue. Confidentiality of the data was assured. The researchers also took care to ensure that the participants understood the feedback during all stages of the research by allowing enough time for questions to be asked and answered. A total of six to eight sessions were held, and all sessions lasted roughly $1 \mathrm{hr}$ each. Self-reflection was facilitated during each session, gradually going over into reflexivity facilitation.

\section{Data analysis}

I acted as one of the external coders in each of the case studies. The research questions and the researchers' conceptual frameworks were constantly in our awareness as we coded the data. In all six studies, a deductive + inductive approach was followed in the data analysis. The researchers worked from the following perspective, explained by Bernard and Ryan (2010): no matter how hard we try there are no purely inductive [or deductive] studies (p. 107). The data were categorised according to predetermined themes found in the literature (Creswell, 2007; McMillan \& Schumacher, 2001) as well as according to the four dimensions of career adaptability: concern, control, curiosity, and confidence (Hartung, 2007; Savickas, 2003, 2005). At the same time, new themes and subthemes in the data were constantly looked out for. For a more complete description of the themes and subthemes in each of the six case studies, see Maree and Pollard (2009), Maree and Crous (2012), Maree and Gerryts (2014), Maree and Hancke (2011), Maree and Hansen (2011), and Maree et al. (2010). The themes and subthemes reported on in this article (see Table 2) are based on these themes and subthemes.

A 'meta' approach to qualitative data analysis was followed in the research to facilitate the emergence of major themes and subthemes. In other words, the themes and subthemes in the six individual studies were analysed in search of 'grander' themes and subthemes (themes and 
Table 2. Themes and subthemes identified through qualitative analysis.

I. Constructing new selves

Subtheme I: Internal skills

Subtheme 2: Resilience-related skills

Subtheme 3: Values

Subtheme 4: Finding suitable roles as outlets for traits

2. Broadened perspective

Subtheme I: Coping strategies orientation

Subtheme 2: Decision making and planning ability

Subtheme 3: Readiness to deal with challenges

Subtheme 4: Adaptability skills

3. Changed identity

Subtheme I: Ability to build on 'failure' experiences

Subtheme 2: Self-discovery

Subtheme 3: Improved self-efficacy

Subtheme 4: Improved sense of self

4. Action orientation

Subtheme I: Augmented self-construction

Subtheme 2: Accomplishment orientation

Subtheme 3: Enhanced career choice

5. Success anticipation

Subtheme I: Excitement about abilities

Subtheme 2: Positive outlook

Subtheme 3: Hope orientation

subthemes that emerged from the six studies collectively). After careful reflection, it turned out that the themes and subthemes from the six case studies could be grouped together logically into the five main themes, described below, which correspond roughly with the first five steps in the life design process. Subthemes of each main theme were also identified (Table 2).

\section{Results}

The main themes that were confirmed in all six studies and the subthemes that emerged during the life design counselling process are summarised in Table 2.

All the themes and subthemes were substantiated by extracts from the participants' narratives (Guichard, Pouyaud, De Calan \& Dumora, 2012). All the declarations of the participants in the six case studies are their assessments of and reflections on the life design counselling process. Themes and subthemes are discussed below.

\section{Theme I: constructing new selves}

The participants gave ample evidence of having constructed 'new' selves (in relation to specific social roles they planned to fulfil in the future) (Guichard, 2005).

Subtheme 1.1: Internal skills. The participants' internal, personal (psychological) skills, including their motivation, openness to change, and ability to understand and express themselves adequately. 
Subtheme 1.2: Resilience-related skills. The participants' ability to deal with contextual challenges satisfactorily.

Subtheme 1.3: Values. The values the participants found meaningful and useful; values they could draw on to guide them when called on to make important decisions.

Subtheme 1.4: Finding suitable roles as outlets for traits. The participants' active devising of new work-related roles that were in line with their main traits/characteristics (Savickas, 2005).

\section{Theme 2: broadened perspective}

The participants demonstrated the acquisition of a broader perspective on matters that initially seemed disheartening and/or daunting.

Subtheme 2.1: Coping strategies orientation. The participants' acquisition of practical strategies to help them cope with change and negotiate transitions.

Subtheme 2.2: Decision making and planning ability. The participants' new-found abilities to make important decisions and to plan the practical implementation of these decisions.

Subtheme 2.3: Readiness to deal with challenges. The participants' added readiness (and willingness) to deal with the challenges at hand.

Subtheme 2.4: Adaptability skills. The participants' enhanced sense of concern, control, curiosity, and confidence about their futures.

\section{Theme 3: changed identity}

All the participants, to a greater or lesser extent, demonstrated that their 'identities' had changed; in other words, they had been changed by the life design process.

Subtheme 3.1: Ability to build on 'failure' experiences. The participants' new-found capacity to see 'failure' as a springboard for future success rather than believing that their 'failures' defined who they actually were.

Subtheme 3.2: Self-discovery. What the participants discovered about themselves, such as their strengths and 'weaknesses'.

Subtheme 3.3: Improved self-efficacy. The participants' increased belief that they were sufficiently strong and talented to succeed in life.

Subtheme 3.4: Improved sense of self. The participants' enhanced sense of who they actually were instead of who they had been led to believe they were by others who did not know them sufficiently well, as well as decreased 'failure orientation' and belief that they could achieve only 'some degree of success' in the future.

\section{Theme 4: action orientation}

The participants demonstrated a desire and willingness to move forward actively rather than merely think, talk, and speculate about what they could do to realise their dreams.

Subtheme 4.1: Augmented self-construction. The participants' enthusiasm to put theory into practice; in other words, to start doing something (construct themselves actively).

Subtheme 4.2: Accomplishment orientation. The participants' ability to implement the action steps agreed upon between themselves and the career counsellors. 
Subtheme 4.3: Enhanced career choice. The participants' enthusiastic carrying out of the steps agreed upon between themselves and the career counsellors to finalise and implement their career choice decisions.

\section{Theme 5: success anticipation}

All the participants gave evidence of anticipating and expecting to achieve success in the future, be it at school, at a tertiary training institution, or in their future career-lives.

Subtheme 5.1: Excitement about abilities. The participants' repeated articulation of their wonder at and appreciation of their abilities that had previously gone either unnoticed or unappreciated.

Subtheme 5.2: Positive outlook. The participants' more positive outlook on their career-lives after the life design sessions.

Subtheme 5.3: Hope orientation. The participants' affirmation of their hope about their futures after the life design sessions.

\section{Discussion}

Some of the themes and subthemes emanating from the present work have been noted, directly or indirectly, by other researchers as well. Strauser et al. (2008), for instance, found that people who had clear career-life goals and found life meaningful displayed less anxiety about their career-lives than people who believed differently. The finding that positive narratives are promoted by the approach advocated in this article echoes Peavy (2004), who also emphasised the pivotal role of language in the construction of meaning. The findings of the present research also confirm Peavy's (2000) view that metaphors and mottos, as well as contextual factors, often play a key role in shaping people's narratives (a process he referred to as dialogical communication, p. 21). The present findings confirm the importance of actively engaging people in constructing personal meanings and plans for the future (in collaboration with career counsellors). The present research results also support Duarte's (2010) view that life design counselling provides career counsellors with a powerful strategy to help clients augment the design of their career-lives and successfully negotiate repeated career-life transitions. The results furthermore support the views of Spain and Bédard (2001) and Bujold (2004) that when career counsellors empower clients to see their career stories as an extension of their life stories, they help them develop an internal locus of control in respect of their career-lives. In other words, they are enabled to construct themselves (utilise their potential) to become the masters of their own fate and the co-creators of their career-life identities, which are no longer regulated by external influences. Put differently, clients are empowered to discover why they exist, to express themselves, and, ultimately, to 'invent' (Bujold, 2004) their own lives.

Overall, the participants demonstrated a new-found capacity and willingness to turn their hurt into hope, their failure into success, and their preoccupations into occupations (Savickas, 2005). Savickas (2013) states that the aim of life design counselling is to help clients author biographical bridges that articulate their personal realities and authorise identities that will help them make transitions in their future career-lives. The emphasis has thus shifted from observing clients objectively to engaging them subjectively (Del Corso \& Rehfuss, 2011).

Savickas (2013) highlights theoretical approaches and techniques developed over the past two decades or so that can facilitate qualitative assessment, including career construction counselling (Savickas, 2011), narrative career counselling (Cochran, 1997), constructivist career counselling (Peavy, 1997), goal-directed career construction counselling (Young \& 
Valach, 2004), career construction counselling from a systems perspective (McMahon, Patton, $\&$ Watson, 2005), self-construction and the discovery of occupational activities and personal plans (Guichard, 2008a), creating metaphors to enable active engagement with the world of careers (Amundson, 2010), storied career counselling (Brott, 2001; Maree, 2011), and (constructivist) career counselling based on the chaos theory (Pryor \& Bright, 2011). Most of these approaches were implemented in the case studies reported on in this article, with the results confirming Savickas' (2013) views and his assertion that '[ $\mathrm{t}$ ]he adaptive fitness of attitudes, beliefs, and competencies - the ABCs of career construction - increases along the developmental lines of [career] concern, control, conception, and confidence' (Savickas, 2014, personal communication).

\section{Concluding comments}

The researchers' subjective interpretation of the data could be regarded as a limitation. In addition, longitudinal research (involving more participants) should be conducted to demonstrate the applicability of the strategy advocated here in broader contexts.

Career counsellors who wish to use the approach put forward in this article should, first of all, familiarise themselves with their clients' career adaptability needs, irrespective of the type of crossroads they are facing. It is immaterial whether clients consult them on school or subject choices, on various kinds of career counselling, or on ways of managing their careers, dealing with work trauma or transitioning from one career to another. Second, it is essential to work collaboratively with clients rather than making decisions on their behalf when conducting the life design intervention. This will enable career counsellors to help clients take ownership of their own lives by assisting them to develop an innovative and positive outlook on their career-lives. Clients can then reconstruct and redesign themselves continually and so enable themselves to deal with the numerous challenges posed by changing environments as and when the need arises. Lastly, the importance of an integrated, qualitative + quantitative approach to career counselling cannot be emphasised strongly enough.

Recommendations for future research include the following. First, life design counselling in one-on-one settings is a promising strategy to help people deal with change and its impact, yet more research is needed on how to apply this strategy in group contexts. Such research should be conducted not only in well-resourced contexts but also in resource-constrained contexts where career counselling is not freely available (if available at all). Second, follow-up studies are needed to determine the longitudinal effect of the strategy in various contexts, for example, comparing the impact of life design counselling on younger and older clients, clients from different gender groups, and clients from different contexts (e.g., clients from affluent areas as well as from disadvantaged areas). Third, career counsellors should (in their research) also focus on the impact of life design counselling on the career development, advancement, and adaptability of their clients. Fourth, career counsellors conducting research should report on their findings on different platforms and forums (e.g., local and international conferences) and endeavour to publish their findings in scholarly journals.

In conclusion: Major changes in the world of work over the past few decades, brought about mainly by the fourth economic wave and the fifth information wave, have affected all countries and continents, including (South) Africa. In an attempt to respond timeously and professionally to the challenges faced by all those affected by these changes (e.g., employers, employees, career counselling theorists, and practitioners and their clients), career counselling theorists began updating the theory and praxis of career counselling. The development of the life design model and counselling strategy to help modern-day workers deal with career-life transitions and related work trauma 
can thus be seen as a 'natural' outcome of major changes in the world of work. Life design is one of the first theories of career counselling. Previously, researchers and scholars such as Super (1957) and Holland (1985) had formulated theories only of vocational behaviour and development.

The research reported on in this article confirms Savickas' (2014, personal communication) view that self-construction, career construction, and life design amount to 're-storying' people's career-lives and that this progression is driven by the tasks, transitions, and trauma occasioned when career-life stories are not completed or lost or when they go 'wrong'. Career construction and life design are advanced by conversations that examine an actor's character, consider agentic intentions and goals, author a future self and work scripts, and prompt action in the real world.

The life design model has been well received in developed countries, yet, regrettably, very little research has been done on the model in (South) African contexts. This article can therefore be seen as a call for research on the topic in South Africa and other developing countries. The six case studies discussed here indicate that life design counselling has the potential to help clients 'invest their identity capital and their stories to cope with the uncertainties prompted by occupational transitions and work traumas' (Savickas, 2013, p. 14). This assertion is supported by the comments of two of the case study participants at the conclusion of the intervention:

I am hopeful. Even if something should happen and things do not go according to plan, I now know that I can do other things; realistic things such as to study education and become a teacher in accounting after which I can continue studying. (Jim)

and

I have learnt that my future is still in my hands, despite what has happened. I can still become who and what I want to become. (Maria)

\section{Funding}

This research received no specific grant from any funding agency in the public, commercial, or not-for-profit sectors.

\section{References}

Amundson, N. E. (2010). Metaphor making: Your career, your life, your way. Richmond, British Columbia, Canada: Ergon Press.

Applebaum, E., Bernhardt, A., \& Murnane, R. J. (Eds.). (2003). Low wage America - How employers are reshaping opportunity in the workplace. New York, NY: SAGE.

Arthur, M. B. (1994). The boundaryless career: A new perspective for organizational inquiry. Journal of Organizational Behavior, 15, 295-306. doi:10.1002/job.4030150402

Arthur, M. B., \& Rousseau, D. M. (1996). The boundaryless career: A new employment principle for a new organizational era. New York, NY: Oxford University Press.

Baruch, Y. (2004). Transforming careers: From linear to multidirectional career paths. Career Development International, 9, 58-73.

Benko, C., \& Weisberg, A. (2007). Mass career customization. Boston, MA: Harvard Business School Press.

Bernard, H. R., \& Ryan, G. W. (2010). Analyzing qualitative data: Systematic approaches. Beverly Hills, CA: SAGE.

Brott, P. E. (2001). The storied approach: A postmodern perspective for career counseling. The Career Development Quarterly, 49, 304-314. doi:10.1002/j.2161-0045.2001.tb00958.x

Bujold, C. (2004). Constructing career through narrative. Journal of Vocational Behavior, 64, 470-484.

Campbell, C., \& Ungar, M. (2004a). Constructing a life that works: Part 1, blending postmodern family therapy and career counseling. The Career Development Quarterly, 53, 16-27. 
Campbell, C., \& Ungar, M. (2004b). Constructing a life that works: Part 2, an approach to practice. The Career Development Quarterly, 53, 28-40.

Campbell, M., Baldwin, S., Johnson, S., Chapman, R., Upton, A., \& Watson, F. (2001). Skills in England 2001 - The research report. Nottingham, UK: DFES Publications.

Cochran, L. (1997). Career counselling: A narrative approach. Thousand Oaks, CA: SAGE.

Creswell, J. W. (2007). Qualitative inquiry and research design: Choosing among five approaches (2nd ed.). London, England: SAGE.

Davies, B., \& Harré, R. (1990). Positioning: The discursive production of selves. Journal for the Theory of Social Behaviour, 20, 43-63.

Del Corso, J., \& Rehfuss, M. C. (2011). The role of narrative in career construction theory. Journal of Vocational Behavior, 79, 334-339.

Duarte, M. E. (2009). The psychology of life construction. Journal of Vocational Behavior, 75, 259-266.

Duarte, M. E. (2010, July). Restructuring career counselling: Objectives and instruments. In R. Van Esbroeck (Convenor), Life design symposium. Symposium presented at the 27th International Congress of Applied Psychology, Melbourne, Victoria, Australia.

Ehrenreich, B. (2002). Nickel \& dimed: Undercover in low-wage USA. London, England: Granta.

Fenwick, T. J. (2004). Learning in portfolio work: Anchored innovation and mobile identities. Studies in Continuing Education, 26, 229-241.

Finegold, D. (1999). Creating self-sustaining, high-skill ecosystems. Oxford Review of Economic Policy, 15, 60-81.

Gershuny, J. (1993). Post-industrial career structures in Britain. In G. Esping-Andersen (Ed.), Changing classes (pp. 136-170). London, England: SAGE.

Guichard, J. (2005). Life-long self-construction. International Journal for Educational and Vocational Guidance, 5, 111-124.

Guichard, J. (Ed.). (2008a). La nouvelle découverte des activités professionnelles et projets personnels [The discovery of occupational activities and personal plans: An updated workshop method]. Paris, France: Editions Qui Plus Est.

Guichard, J. (2008b). Proposition d'un schéma d'entretien constructiviste de conseil en orientation pour des adolescents ou de jeunes adultes [Outline of a life designing counseling interview for adolescents and young adults]. L'Orientation Scolaire et Professionnelle, 37, 413-440.

Guichard, J., Pouyaud, J., De Calan, C., \& Dumora, B. (2012). Identity construction and career development interventions with emerging adults. Journal of Vocational Behaviour, 81, 52-58.

Gurri, M. (2013). The revolt of the public and the crisis of authority in the new millennium (Kindle DX version). Retrieved from http://www.Amazon.com

Hall, D. T. (1996). Protean careers of the 21st century. Academy of Management Executive, 10, 8-16.

Handy, C. (1995). The age of unreason. London, England: Arrow books.

Hartung, P. J. (2007). Career construction: Principles and practice. In K. Maree (Ed.), Shaping the story: A guide to facilitating narrative counselling (pp. 103-120). Pretoria, South Africa: Van Schaik Publishers.

Hartung, P. J. (2011). Career construction: Principles and practice. In K. Maree (Ed.), Shaping the story: A guide to facilitating narrative counselling (pp. 103-120). Rotterdam, The Netherlands: Sense Publishers.

Holland, J. L. (1985). Making vocational choices: A theory of vocational personalities and work environments (2nd ed.). Upper Saddle River, NJ: Prentice Hall.

Keep, E., \& Brown, A. (2005). Moving beyond discussions about paradigm shifts - Creating space for multiple meanings and narratives on changing patterns of employment and careers. Career Research and Development, 13, 11-19.

McMahon, M., Patton, W., \& Watson, M. (2005). My system of career influences. Camberwell, Victoria, Australia: ACER Press.

McMillan, J. H., \& Schumacher, S. (2001). Research in education: A conceptual introduction (5th ed.). New York, NY: Addison Wesley Longman, Inc.

Mainiero, L. A., \& Sullivan, S. E. (2005). Kaleidoscope careers: An alternative explanation for the opt-out revolution. Academy of Management Executive, 19, 106-123.

Maree, J. G. (2010). The career interest profile (Version 2). Randburg, South Africa: Jopie van Rooyen and Partners. 
Maree, J. G. (2011). The career interest profile (Version 3). Randburg, South Africa: Jopie van Rooyen and Partners.

Maree, J. G. (2012a). A (guided) meta-reflection theory of career counseling: A case study. South African Journal of Higher Education, 26, 670-690.

Maree, J. G. (2012b). Career adapt-abilities scale - South African form: Psychometric properties and construct validity. Journal of Vocational Behavior, 80, 730-733. doi:10.1016/j.jvb.2012.01.005

Maree, J. G. (2013). Latest developments in career counselling in South Africa: Towards a positive approach. South African Journal of Psychology, 43, 409-421.

Maree, J. G. (2014). Career construction with a gay client: A case study. British Journal of Guidance \& Counselling, 42, 436-449.

Maree, J. G., \& Crous, S. (2012). Life design career counselling with an abandoned adolescent: A case study. Journal of Psychology in Africa, 23, 106-113.

Maree, J. G., \& Gerryts, E. (2014). Narrative counselling with a young engineer. Journal for Psychology in Africa, 24. doi: http://dx.doi.org/10.1080/14330237.2014

Maree, J. G., \& Hancke, Y. (2011). The value of life design counselling for an adolescent who stutters. Journal of Psychology in Africa, 21, 483-490.

Maree, J. G., \& Hansen, E. (2011). Identifying and dealing with the adaptability needs of an unwed pregnant teenager. Journal of Psychology in Africa, 21, 211-221.

Maree, J. G., Nkambule, T., Erasmus, P., Hansen, E., \& Symington, S. (2010, July). Career adaptability in South Africa: Test of a model and measure. In Savickas M. L. (Chair), Career adaptability: Model and measure. Invited symposium presented at the 27th Congress of Applied Psychology, Melbourne, Victoria, Australia.

Maree, J. G., \& Pollard, Z. (2009). The impact of life design counselling on adolescents. Journal for Psychology in Africa, 19, 169-176.

Moynagh, M., \& Worsley, R. (2005). Working in the twenty-first century. Leeds, UK: ESRC Future of Work Programme and King's Lynn, The Tomorrow Project.

Parsons, F. (1909). Choosing a vocation. Boston, MA: Houghton-Mifflin.

Parsons, F. (2005). Choosing a vocation. Broken Arrow, OK: National Career Development Association.

Peavy, R. V. (1997). Sociodynamic counseling: A constructivist perspective for the practice of counseling in the 21st century. Victoria, British Columbia, Canada: Trafford Publishing.

Peavy, R. V. (2000). A sociodynamic perspective for counselling. Australian Journal of Career Development, 9, 17-24.

Peavy, R. V. (2004). Sociodynamic counselling: A practical approach to meaning making. Chagrin Falls, $\mathrm{OH}:$ Taos Institute.

Pryor, R., \& Bright, J. (2011). The chaos theory of careers. New York, NY: Routledge.

Pulakos, E. D., Schmitt, N., Dorsey, D. W., Arad, S., Hedge, J. W., \& Bornman, W. C. (2002). Predicting adaptive performance: Further tests of a model of adaptability. Human Performance, 15, 299-323.

Savickas, M. L. (1993). Career counseling in the postmodern era. Journal of Cognitive Psychotherapy: An International Quarterly, 7, 205-215.

Savickas, M. L. (1997). Career adaptability: An integrative construct for life-span, life-space theory. The Career Development Quarterly, 45, 247-259.

Savickas, M. L. (2002). Career construction: A developmental theory of vocational behavior. In D. Brown (Ed.), Career choice and development (pp. 149-205). San Francisco, CA: Jossey-Bass.

Savickas, M. L. (2003). Advancing the career counseling profession: Objectives and strategies for the next decade. The Career Development Quarterly, 52, 87-95.

Savickas, M. L. (2005). The theory and practice of career construction. In S. D. Brown and R. W. Lent (Eds.), Career development and counselling (pp. 42-70). Mahwah, NJ: Wiley.

Savickas, M. L. (2011). Career counselling. Washington, DC: APA.

Savickas, M. L. (2013). Life design: A paradigm for career intervention in the 21 st century. Journal of Counseling \& Development, 90, 13-19.

Savickas, M. L., Nota, L., Rossier, J., Dauwalder, J.-P., Duarte, M. E., Guichard, J., . . Van Vianen, A. E. M. (2009). Life designing: A paradigm for career construction in the 21th century. Journal of Vocational Behavior, 75, 239-250. 
Savickas, M. L., \& Porfeli, E. (2012). The Career Adapt-Abilities Scale: Construction, reliability, and initial validity of the USA Form. Journal of Vocational Behaviour, 80, 661-673. doi:10.1016/j.jvb.2012.01.005

Soresi, S., Nota, L., Ferrari, L., \& Solberg S. (2008). Career guidance for persons with disabilities. In J. A. Athanasou and R. Van Esbroeck (Eds.), International handbook of career guidance (pp. 405-417). Dordrecht, The Netherlands: Springer Science.

Spain, A., \& Bédard, L. (2001, September). De l'enracinement au d'eploiement: La creation de son identite professionnelle. In C. Yelle \& J. Leahey (Chairs), Ce qui lie, ce qui d'elie, ce qui relie: Histoire de vie. Symposium conducted at the meeting of the Reseau quebecois pour la pratique des histoires de vie, Saint-Jean-de-Matha, Quebec, Canada.

Strauser, D. R., Lustig, D. C., \& Ciftci, A. (2008). Psychological well-being: Its relation to work personality, vocational identity, and career thoughts. The Journal of Psychology, 142, 21-35.

Super, D. E. (1957). The psychology of careers. New York, NY: Harper \& Row.

Super, D. E. (1990). A life-span, life-space approach to career development. In D. Brown and L Brook (Eds.), Career choice and development: Applying contemporary theories to practice (pp. 197-261). San Francisco, CA: Jossey-Bass.

Ungar, M. (2012). Social ecologies and their contribution to resilience. In M. Ungar (Ed.), The social ecology of resilience: A handbook of theory and practice (pp. 13-32). New York, NY: Springer.

Young, R. A., \& Valach, L. (2004). The construction of career through goal-directed action. Journal of Vocational Behavior, 64, 499-514.

Zunker, V. G. (1998). Career counseling: Applied concepts of life planning (5th ed.). Pacific Grove, CA: Brooks/Cole Publishing Company. 